\title{
New Sundanese dance for new stages
}

\author{
Irawati Durban Ardjo
}

In this essay I will discuss part of my life in dance, beginning with my experiences studying and performing dance in an era when conditions were very different to those of today both in Indonesia and abroad. My essay, unlike other contributions to this volume except for Melani Budianta's, are based on personal experience. While Melani's essay recounts her personal experience and the cultural life of Peranakan Chinese in Malang, a town in East Java, I am writing about the experience of a Sundanese dancer on the national stage and my travels abroad which influenced developments in the arts in Indonesia. ${ }^{1}$

When I came to write about this experience, I discovered many things of which I had previously been little aware. The time, during the Soekarno period, when I began to know dance, to love it and to participate in it so enthusiastically was in fact an important period in the young nation in its efforts to shape Indonesian-ness; as a people, as a nation and in the arts. President Soekarno was a statesman and an artist who loved the arts, particularly the dance of Indonesia's regions. The period that forms the timeframe of this book, 1950-1965, is fitting because we can consider it the period when the foundation pillars were set in the search for national culture and in awareness of the importance of regional arts within it. Furthermore, political and cultural contacts with the outside world resulted in a new context for regional dance and dancers, and new stages for them.

CHANGING TIMES, CHANGING ARTS

The life chapter I am writing about begins in 1948, when I returned to Bandung from our evacuation in 1946 during the revolution after

1 There is one small point of crossover, namely when Melani mentions the new dance Kunangkunang (Fireflies). This dance was performed by the Viatikara group, of which I was a member, when it toured Malang in the 1960s. 
South Bandung had been set alight. The Allied Forces had given the ultimatum that on 24 March 1946, all Indonesian soldiers and freedom fighters had seven hours (until midnight) to leave the southern part of the city of Bandung, now under Allied control. It was not only the soldiers and freedom fighters who rejected the return of the Dutch. The people united, and they were prepared to leave the city, burning storehouses and even their own homes so that they would not be used by the Dutch. My family joined those who evacuated, first to an area south of Bandung, then to Garut, Yogyakarta and Jakarta, finally returning to Bandung on 7 January, 1948.

In colonial times, the Sundanese lived in a highly stratified 'feudal' social system. Even though there were no longer kings in Priangan, their descendants had become bupati (regents) and lived like little kings. Their position and that of the aristocrats (menak) was far above the people. Relations between the two social groups were not equal; rulers were in the upper strata and servants in the lower strata. In between, were middle aristocrats and traders.

I was born in 1943, and lived in the time of early independence with traces of the 'feudal' code of conduct, which my mother then still instilled in her children (my father died eleven months after I was born, in 1944). This conduct included: bowing one's head and not speaking or looking around while eating; never contradicting elders and remaining silent and never interrupting when any elder was speaking; speaking politely and quietly; when walking in front of anyone older than oneself, bending over and keeping the right arm straight facing downwards, and if they were sitting on a mat, crouching as low as possible. The basic principle was that we were not to stand or sit higher than anyone older or anyone of respect. Females had to stay at home, and if they ventured outside of the home, they had to keep their gaze straight ahead, and not look around them or smile. My older brothers and sisters still had to make the sign of obeisance called anun (hands in prayer position raised to a bowed head, with the thumbs just touching the nose) whenever they gave anything to our grandfather. I have only vague memories of this.

In the era that followed, table rules and ways of communicating loosened up. Some loosened rules of etiquette spread downwards, such as the custom of bending one's body slightly and uttering 'punten' (excuse me) when passing anyone at all which became part of Sundanese etiquette right to village level, and has endured. At the same time, by 1958 the requirement that females stay in the home, and rules for their behaviour, had relaxed considerably, which benefited me for Mother understood the need for me to attend many dance classes and performances outside of school activities. My rel- 
ative freedom inspired envy in my older sisters. This was the beginning of my following the changing times through dance.

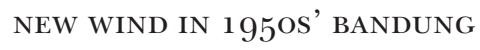

The world of dance I experienced as a child was under the tutelage of сеu (sister) Itim, my sister in law, who taught Arabic dances, the 'Balloon dance' to a Strauss waltz, and an 'Irian Samba' danced to a melody of the same name. I also took ballet lessons with Gina Meloncelli, a ballet teacher in Bandung of Italian descent. I was familiar with Sundanese dance via broadcasts on the Bandung station of the national radio, Radio Republik Indonesia (RRI). In the 1950s, if I am not mistaken, the classic gamelan degung melody Pajajaran was broadcast daily when RRI Bandung went to air. And on Sunday mornings, there was the stirring gamelan for Sundanese martial art called kendang penca. Apart from this, Sundanese dance was taught on radio, with dance instructions called out to the gamelan accompaniment. When my older sister tried to learn from this program, I would copy her movements. This was no easy matter because we couldn't understand all the phrases.

When in 1956 I began to study Sundanese dance more seriously after two previous unsuccessful attempts, it transpired that the dance I learnt from Rd. (Raden, a Sundanese aristocratic title) Tjetje Somantri at his school Badan Kesenian Indonesia (BKI, Body for Indonesian Arts, 1948-1958) was dance that was beginning to discard 'feudal' influences. The first dance I studied was the slow tempo tari Dewi, wearing a batik wrap-around cloth the edge of which was rolled and left to drape on the floor to be flicked right and left by the foot. The tari Dewi still had an aristocratic Sundanese feel with its elements of the Tayub dance (a male aristocratic dance) and Badaya (a female dance performed by noble families), but it also contained elements of Tjetje Somantri's own female dance style. (Subsequently, BKI often produced female dances in this new style that was named wanda anyar, with various characters and forms that had not existed previously). ${ }^{2}$

In his own account of the history of his dance school BKI, Oemay Martakusuma writes that in 1948, upon returning to Bandung from evacuation, those who established the school were himself, Tb. (for Tubagus, a title of nobility from Banten) Oemay Martakusuma as head, Rd. Barnas Prawiradiningrat (previously secretary to the Resident of Garut) as deputy head, and S.M. Thaher from West Sumatra

2 For more on Tjetje Somantri, Oemay Martakusumua, Badan Kesenian Indonesia and the history of Sundanese dance, see Irawati Durban Ardjo 2007 and 2008. 
as secretary (Oemay Martakusuma 1977). Together they raised the profile of various regional arts, because during Dutch times these arts had been given no opportunity to develop. Their reason for doing so was to fortify youth against outside influences which they could see were surely to come. Books in the Sundanese language, the Indonesian-language journal Budaya and the Sundanese-language journal Budaja all discussed arts and culture in West Java. ${ }^{3}$ The group established various arts courses, including Sundanese dance, gamelan, traditional sung poetry and angklung, Javanese dance and gamelan, dance and music from Sumatra and West Sumatra, Balinese dance and gamelan, painting (the group Jiva Mukti led by Barli) and drama. Young people flocked to attend these courses, especially school students, and also members of the Lembaga Kebudajaan Rakjat (LEKRA, Institute of People's Culture). ${ }^{4}$

Apart from the excitement of establishing courses in the arts in the early 1950s in West Java, another thing that felt new was the arrival of new opportunities for women in the arts. In colonial times, women from 'good' families were not permitted to dance in public, because this carried the connotation of prostitution from the tradition of ronggeng (female dancer-singers in folk performance). The positions of aristocrats and the people were far apart, and ordinary people were not permitted to learn or to enjoy the arts of the nobility. However, after independence, the spirit of democracy was strong at BKI. Through Tjetje's dance compositions, which were primarily designed for women, women from all social strata could learn dancing together at BKI, and they also danced in highly respectable performances before important personages.

It was not only women in Priangan who experienced these changed conditions, it seems. The situation was similar in Makassar, South Sulawesi, as Barbara Hatley discusses in this volume in relation to the experience of Andi Nurhani Sapada. Andi Nurhani Sapada's mission to perform the Pakarena dance, a mission that

3 The journal Budaya (in the Indonesian language) was published in Bandung by the office of the Department of Education, Training and Culture (Djawatan Pendidikan, Pengadjaran dan Kebudajaan, P.P. \& K.) from 1948-1952. In November 1952 (edition number 28) the journal moved to Yogyakarta and the office of P.P. \& K. took over the publishing, but renumbering issues from 1. The Bandung office of P.P. \& K. continued to publish a journal in the Sundanese language, titled Budaja, with the issues starting from number 1.

4 An example of LEKRA's attention to West Javanese music can be found in Rhoma D.A. Yuliantri and Muhidin M. Dahlan (2009:10-12) where there are two photos reproduced from Budaja 13 (1956):23 of female LEKRA members at BKI practicing on gamelan instruments in wooden boxes rather than traditional low carved frames. Oemay designed these wooden boxes to make them easy for young people to carry, and also to raise the status of the musicians who sat on chairs to play, unlike the traditional instruments played by musicians who usually sat on the floor (interview with Oemay, 1976). 
President Soekarno supported, was similar to Tjetje's. They both designed dances for women, a category that previously did not exist (other than dances for women from nobility) because previously women could not dance in public. And subsequently, through their efforts, dance for women flourished. ${ }^{5}$

\section{MEETING NEW CHALLENGES: BKI AND NEW DANCES}

Oemay, in his 'Overview of West Javanese arts' (Selayang pandang tentang kesenian daerah Jawa Barat), tells of the revolutionary times when he and Tjetje met each other again in Garut, which had become the Priangan capital (Tom 1952). With the assistance of the Secretary to the Priangan Resident, Rd. Barnas Prawiradiningrat, at the end of 1946 they renewed the activities of Sekar Pakuan, which Oemay, with the Bupati of Bandung as patron, had established in 1935 as a kind of arts society with all arts organizations in Bandung as members. When Japan occupied Indonesia in 1942, Sekar Pakuan was dissolved and became part of Keimin Bunka Shidoso, the cultural centre under the Information Office of the Japanese military government, with the new name Badan Kesenian Djawa Barat (BKDB, Body for West Javanese Arts). In 1947, an all-Indonesia congress of civil servants (pamongpraja) was held in Garut, led by President Soekarno. Following this, President Soekarno frequently held important events in Garut, with BKDB providing dance and drama entertainment for closing ceremonies. ${ }^{6}$ Once the fighting had ceased, President Soekarno continued to support the performances of Oemay and BKI, which he considered fitting for entertaining foreign dignitaries. Every foreign dignitary who visited Indonesia had to watch BKI dance, in Bandung, at the state palace in Jakarta, or at the palaces at Cipanas and Bogor.

Both Tjetje Somantri the choreographer and Oemay Martakusuma who established BKI in 1948 and later became Head of the

5 There are also differences between them. Andi Nurhani Sapada was a girl from an aristocratic family, but was not familiar with music or dance because she had lived outside of her area from her youth, as her father worked in the area of Ambon (interview with Andi Nurhani Sapada, July 2009). However, the demands of the time for a dance that was uniquely from Makassar, particularly requested by President Soekarno, drove her, with the support of her husband who was Bupati in kabupaten Sidenreng, Rappang, to pioneer a South Sulawesi dance that was based on various traditional dances from various kabupaten. (See further Barbara Hatley's essay in this volume).Tjetje, on the other hand, was an expert on Sundanese dance who had studied all kinds of dance since 1911. President Soekarno liked his creations, and Tjetje was also supported in his work by Oemay as head of the local office of culture (Djawatan Kebudajaan Djawa Barat) and other experts whojoined BKI. 6 Interview with Oemay Martakusuma, 1977. 
Djawatan Kebudajaan Djawa Barat in 1950 when this office was established, were of nobility and had received their education at Dutch schools. Western taste and a modern aura are very evident in the dances they created. Oemay was driven by an ambition to create female Sundanese dance, which had not previously existed, and thus in the newly independent era he got the idea to 'ballet'ize Sundanese dance. Tjetje, who had mastered various forms of dance from Sunda, then translated this idea, including his creation of the Butterfly dance (tari Kukupu), which was made to look spectacular and 'modern' with the aid of Oemay's costume creations. Even the accompaniment was new, arranged by Kayat with songs and a new style of playing that gave the dance spirit.

Tari Kukupu was created in 1952 and performed for the first time at the conference of the World Health Organization at the Savoy Homann hotel in Bandung, on 3 September. Eight dancers rising and falling to the melancholic gamelan accompaniment, wearing beautiful brightly coloured costumes depicting the peaceful beauty of nature, was seen to be a perfect match to depict the natural beauty of Priangan. The dance movements were full of Sundanese dance idiom albeit with innovation, but the novelty of the dance was particularly in the concept, namely as a dance about a creature depicted for itself, and not connected with a human figure, as for instance is the case with dances with the Garuda bird or the deer in the Ramayana story. ${ }^{7}$ The Kukupu dance became a must for President Soekarno when entertaining his guests, both for performances in Indonesia and touring in many cultural missions abroad.

\section{GETTING TO KNOW ARTS FROM OTHER AREAS}

When the Indonesian republic was newly independent, the state and President Soekarno required new official ceremonies, and with them came the need for art forms and ways of presenting them that were fitting for these new conditions. Traditional performance forms that had previously been local and watched only by local audiences were suddenly raised to the national and even international stage. The process of familiarization between regional artists who watched each other's skills broadened their horizons, and also made a highly significant contribution to the development of the arts from 1950 through to the early 1960s, as I myself experienced.

7 Interview with Dedi Djamhur, 2001. 
State performances before President Soekarno were routine events in the 1950s and early 1960s. The performances took place on stages, on floor level, in the gardens of the State Palace (Istana Negara) or the Istana Merdeka, or at the Sports Stadium (Istana Olah Raga, Istora) at Senayan, Jakarta, where the audience sat in tiers surrounding the performers.

One important recurring performance was held annually at the Istana Negara to celebrate Independence Day on 17 August. Performances were held in the inner garden of the palace, after the dinner attended by high-ranking government officials, foreign ambassadors, and specially invited Indonesian and foreign guests. All the invited guests and their spouses attended. A variety of regional performances was presented on a specially constructed stage in the centre of the garden.

The program might begin with the Gending Sriwijaya dance from Palembang danced by five to seven dancers in resplendent red and gold regional costume, while the host President Soekarno greeted his guests and invited the most honoured guests to taste the betel nut carried by the dancers, who would dance with their long, thin gold fingernails, carrying the special tray. The beautiful sound of the singers would fill the area, creating an impression of the glory of the kingdom of Sriwijaya in days gone by. Another regional dance hailing from other royal halls was the Pakarena dance from Makassar, South Sulawesi, which Andi Nurhani Sapada had condensed. The nine dancers, wearing beautiful loose long blouses (baju bodo) and huge gold ornaments on their heads, chests and arms, moved gracefully and calmly, in contrast to the frenetic loud music of the drums and strident reed instrument, slowly waving small scarves and white fans that they held in their hands. The Seudati dance performed by twenty young Aceh youths appeared extremely energetic and exciting, dominating the space. With no musical accompaniment, only the singing of the dancers themselves led by the lead singer, the clicking of fingers, the slapping of bodies and stamping of feet, this dance from Aceh was thrilling. (Today the popularity of Seudati has been replaced by the Saman dance performed by dancers moving together while sitting in a line.) From Bali, the dance most often performed was the Temulilingan, which depicted a pair of bees, pliant and lively, accompanied by shrill gamelan music that pierced the night. Or the Kecak dance performed by dozens of male dancers seated while chanting and moving rhythmically in unison, which never failed to impress the audience. From Central Java there was the dance duet of the characters Bambangan and Cakil, or the Gatotkoco dance that displayed lively, strong-style dance technique. Bandung's offering was always the Kukupu dance. The atmo- 


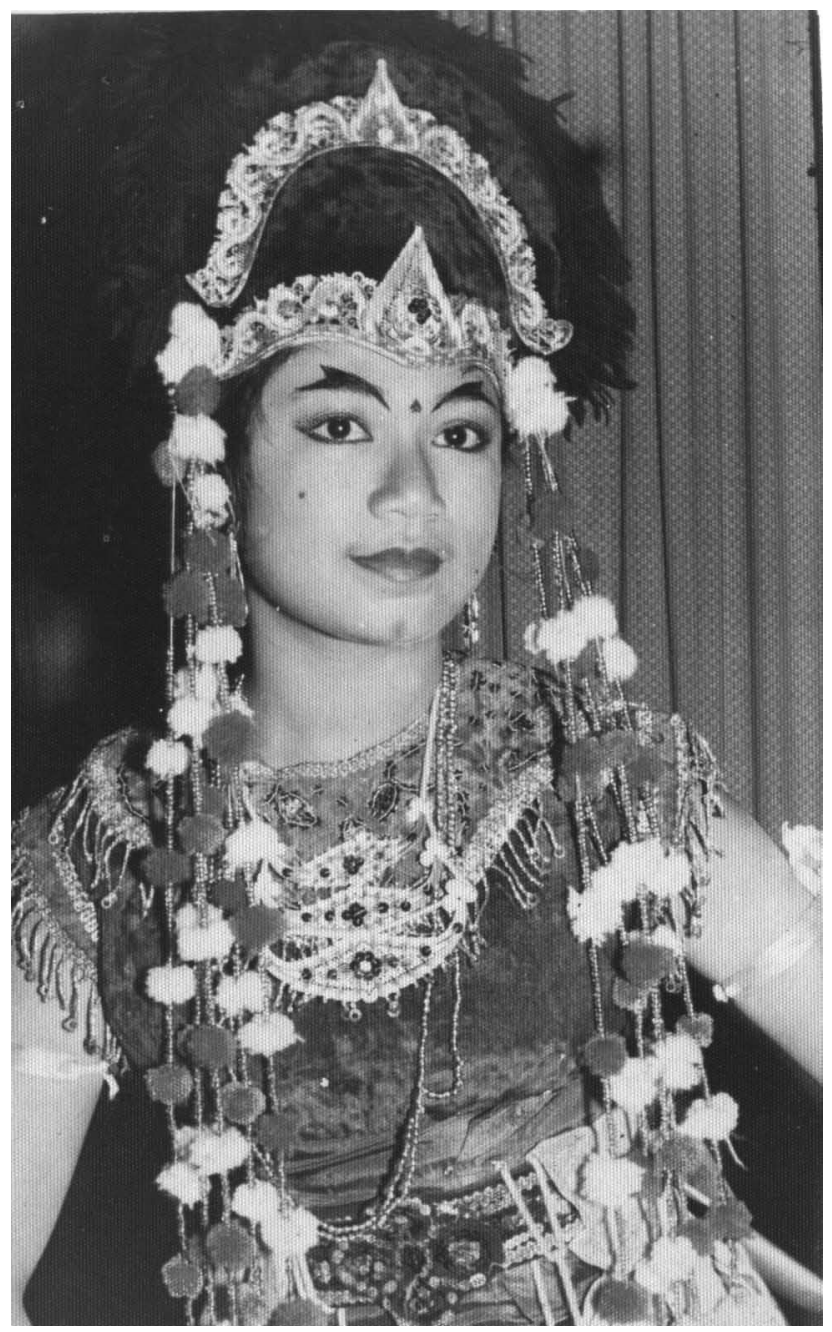

Irawati performing the Topeng Koncaran dance at the Savoy Homann Hotel in 1958. (collection Irawati Durban Ardjo) 
sphere of the extensive palace gardens was enhanced by the arrival of eight brightly coloured butterflies fluttering around. It was at opportunities such as these that the artists began to get to know dances from other areas. This familiarization with and appreciation of the variety of Indonesian dance fostered a sense of pride in the diversity of Indonesia, and increased our love for regional dance.

Apart from the Independence Day performances, there were frequently receptions for state guests, held at the palace or in other venues, for instance in Bandung at the Savoy Homann hotel, the official residence of the Governor of West Java (Gedung Pakuan), or the Bumi Sangkuriang reception hall. I often danced at all these places. When in 1962 the construction of the sports stadium at Senayan (Istora Senayan) was completed for hosting international sports events, colossal performances were often included. I participated in the arts program of the Asian Games on 24 August 1962 and again at the Games of the New Emerging Forces (GANEFO) on 10 November 1963. Tjetje appointed me as dance trainer and in charge of costumes for both these mass performances.

\section{EXPERIENCE ABROAD}

Apart from the opportunities to peek at each other's performances at the state occasions in Jakarta, which put us in awe of one another and encouraged us to study the arts of other regions, the preparation for cultural missions abroad gave us more extended opportunities for this, and were extremely important for getting to know one another and interacting on a personal level. This continued while we were abroad on tours that often lasted for months at a time.

In the Soekarno period, a large number of arts groups was sent abroad, as Jennifer Lindsay discusses in her essay in this volume. I went on seven of these missions, namely 1957 (CzechoslovakiaHungary-Poland-Russia-Egypt), 1961 (The People's Republic of China (PRC)-North Korea), 1962 (Thailand), 1963 (ThailandTaiwan), 1964 (USA-France-Holland) and twice in 1965 (Thailand, PRC-North Korea-Japan). I will relate some experiences that influenced my subsequent activities as a dancer, choreographer and dance teacher, as an example of the interaction between the experiences of artists abroad and developments in the arts in Indonesia at this time.

Before I went overseas for the first time with the cultural mission in 1957, an international sense was not entirely foreign to me. My 
family spoke Dutch at home, and one of my mother's good friends was Dutch (Tante Luus whose home was packed full of antiques, from floor to ceiling). My experience at the Christian primary school (Santa Ursula) and at Santa Angela junior high school and high school through to 1961 with Indonesian, Dutch and German teachers and strict tuition in English, French and German, had inadvertently created an international atmosphere around me. The ballet films The dying swan and The red shoes also fanned my dream to become a ballerina, and I dabbled with ballet lessons for four months.

When my teacher, Tjetje Somantri came to the house to ask me to join the cultural mission overseas, my mother was dubious and asked my older brother's opinion. He replied: 'Let her go, because we will probably never be able to pay for her to go abroad.' And so it was that I joined rehearsals and was prepared for travel abroad together with my dancer friends Indrawati Poerwo and Karmilah, the male dancer Dida Hasanuddin, and Kandi the drummer. Oemay made our dance costumes especially for us, we were given matching suitcases, and the tour managers in Jakarta made our uniform woollen coats.

My first tour abroad was to East Europe and Egypt for three months from July to October 1957, and for me, still a child, it opened windows on the world and made a deep impression. The other dancers, musicians and singers were adult, but we three Sundanese dancers were just 13 (Indra) and 14 (Karmilah and myself) years old.

Before we departed, we had rehearsals one or two afternoons in Jakarta at Jalan Pegangsaan Timur 56, on the back terrace of the house where Indonesia's independence had been proclaimed. Every region showed what it was going to perform abroad. From Java there was the Kudo-kudo dance by two male dancers, the Golek dance by two beautiful female dancers, and the Bambangan-Cakil dance by a male and female dancer. I was amazed at the suppleness of the Cakil dancer. Then it was our turn. Kandi the drummer had to perform with Javanese musicians, but he had already rehearsed with them three years earlier in Yogyakarta for one month before the 1954 cultural mission to China. The gamelan sounded dreadful, unco-ordinated and clanging, because apart from Kandi none of the musicians was Sundanese, and the instruments were also not Sundanese but Javanese, and they are different. All we could do was follow the drum. Dida Hasanuddin had to do the same with his dance, which was also jarring. Luckily, Kandi's dynamic and steady drumming saw him through, and enlivened Dida's strong dancing. 
From North Sumatra, there were four female dancers accompanied by accordion and drum. They danced Tanjung katung, Serampang XII, Ma'Inang and Hitam manis with gentle but agile movement, their arms swaying. Their dance looked very different to the Javanese and Sundanese dances with their complex hand, head, and body movements, and feet rooted more solidly to the ground.

At the end, all dancers came together to learn to sing Batak songs together with Gordon Tobing, and with him accompanying on guitar. We sang various Batak songs like Sing-sing so, Sigule pong, Butet, Nasonang do hita na dua and Rege-rege and ended with the Indonesian song composed by Ismail Marzuki, Rayuan Pulau Kelapa. When we were on tour abroad, dancers would appear on stage to sing with Gordon Tobing, and this part of the program was popular with audiences. At the curtain call, the entire ensemble would sing Rayuan Pulau Kelapa. But our singing wasn't limited to the stage. When we were in the bus, or whenever the mood and time was right, Gordon and his guitar would call us to sing, and this too fostered a feeling of intimacy between the members of the group, and with the local organizing committee.

Our first destination was Prague, the capital of Czechoslovakia. We performed at the Smetana Theatre, where the stage was wider than anything we had ever experienced before. We three Sundanese dancers followed the floor pattern that Oemay had taught us, and our Sulintang or Golek dance always opened the program. The audience applauded enthusiastically when we finished, and we had to return to take another bow. Perhaps it was because we were still so young, and we took our bows shyly. When we were not performing ourselves, and while standing in the wings, we could watch the whole evening's program. And at the end of it all, we went back on stage to sing together for the close of the performance, to the audience's applause.

City after city we passed through, country after country; Czechoslovakia, Poland, Hungary, USSR and Egypt. We toured for three months showing the beauty of Indonesia's arts to attract the world's support for the young nation.

\section{WATCHING PERFORMANCES}

Apart from performing ourselves, we also watched various kinds of performances. We saw various kinds of European folk dancing, with lively leg and feet movement, jumping and stamping. Dozens 
of dancers danced together on one stage executing movements in unison, with energetic music and song, and wearing big, heavy costumes. The women's voices sounded as though it was forced from their throats. The songs depicted the beauty of the hills, valleys, stony mountains and tidy woods of Europe, all so totally different from unruly, expansive tropical forests and intermittent patches of rice fields.

It was difficult for us to differentiate the folk dances from the four Eastern European countries we visited, apart from the costume and decoration. Our immediate impression was that they all involved unison movement with almost identical leg movements, the dancers sometimes moving very closely together, holding each other by the hand or around the waist, with happy expressions as they sang. Sometimes the male dancers would move more adroitly and leap up. All the dancers wore shoes, high socks, and kicked their legs. They ran, leapt forward and back, and could move rhythmically from one floor pattern to the next.

This was all totally different from our classical dance, where male and female dancers must not touch each other, where the female dancers must keep their gaze low, their smiles stifled, and never, ever show their teeth. Our feet were shoeless and slid gently, taking slow steps in various patterns, and in a tempo that never allowed for running.

When we attended orchestral concerts with over 50 musicians performing music by famous composers like Mozart, Beethoven and Tchaikovsky, only a few of us understood. On the whole, we tried to enjoy such performances while watching the way the violin and cello players all moved as one, together with the other instruments under the direction of the conductor with his baton.

When we watched opera or operettas, the musicians were down in the orchestra pit. The stage had more interesting decoration, with backdrops, lighting, and other effects. And then there were the entries and exits of the performers in their various costumes, their acting in small and large groups, sets that changed slowly while the curtain was still up or dramatically while the curtain was down, and the beautiful singing, booming out rich and loud, or long, trembling high notes.

Russia (the USSR) was famous as the centre of ballet. At the Stanislavski and Nemirovich-Danchenko Theatre in Moscow, Swan lake transported us to another world, a world of magical dreams that we had never before imagined. Scenes moved fluidly from one to the next, and left us deeply impressed. The music, the staging, the dance, the acting, the floor patterns, the costumes, the technical stage effects - all of these kept us wide-eyed, hearts skipping 


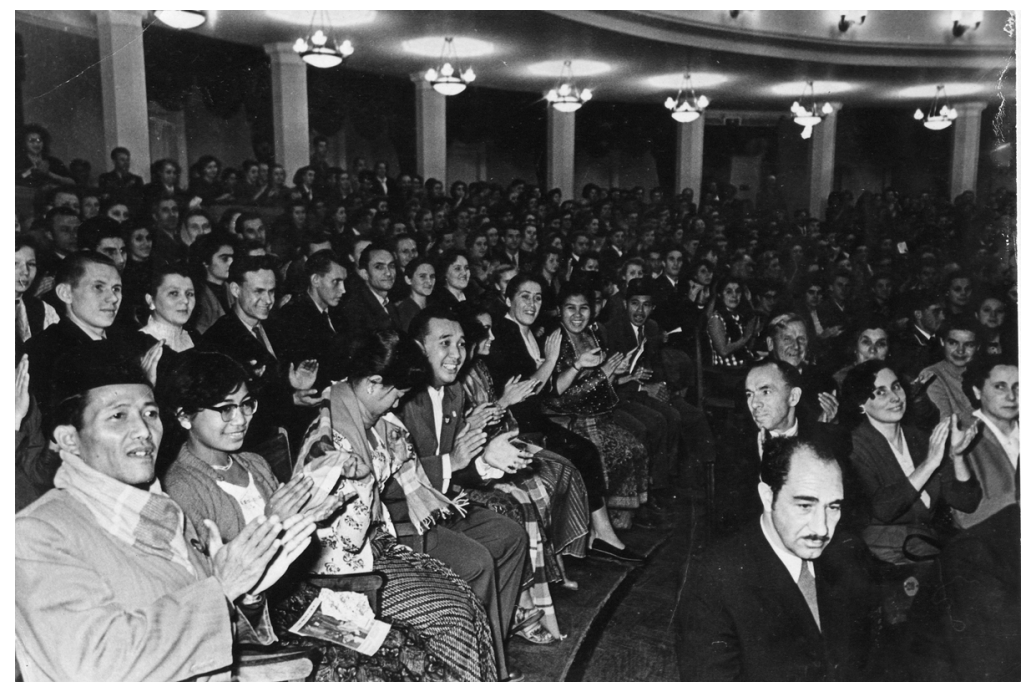

Watching Swan lake in Moscow, 1957. Irawati is second from left. (collection Irawati Durban Ardjo)

a beat. When the performance was over, it was as though we had truly woken from a beautiful dream, between consciousness and half-dreaming.

Apart from dance and music, in Leningrad we watched worldclass circus, the performance form loved by all ages. The atmosphere in the tent was totally different. All kinds of attractions were rolled out. We were impressed and entertained by the lighting, the sound, the movement of the circus performers, the animals and the clowns.

When we were in Egypt at an evening reception, we three Sundanese dancers were seated right at the edge of the stage. After the dinner was over, a pretty belly-dancer appeared, twisting and undulating her body. Her costume exposed her belly and hips, to show the supple and sensual movement. This dance was very different to the performances we had seen in the other countries. It had a strange beauty, but when the dancer moved her belly muscles and hips, we were so astonished we got the giggles.

We visited all kinds of performance venues, as well as museums, palaces, pyramids and historical sites, and saw statues, carvings, paintings, handicrafts and amazing parks. All these experiences made us aware that natural beauty and artistic beauty are universal. 
Apart from watching performances, in some countries we were also taken to see the arts training behind the scenes. In Czechoslovakia we visited SLUK (Slovensky Ludovny Umelecky Kolektif) in Bratislava, a school for folk music and dance housed in an ancient castle-like building outside the city. We were warmly greeted by elaborately dressed dancers in heavy embroidered costumes that weighed between 5-10 kilograms. We then watched them perform in a grand hall. Indonesia was not strange to this group. They had first toured Indonesia in 1954, performing in Jakarta, and again in January 1957. On this second visit they had performed in Bandung at the Chung Hua Tsung Hui building, but I did not manage to see them.

In the Soviet Union we were taken to one section of a row of buildings in Moscow. The building did not look unusual, but it turned out to be a ballet school, perhaps Bolshoi. We were invited to watch ballet classes, with children of different ages taught in different groups, from those aged about ten through to teenagers. The students stood at the barre, wearing short, light rehearsal costumes, socks and ballet shoes. A teacher would give a command, and they would follow with simple, short movements to the accompaniment of a piano played in the corner of the room. They moved together in an orderly, uniform way. Their bodies were led gradually through dance movements of increasing technical difficulty.

THE IMPACT OF TOURS ABROAD

The impact of so many experiences in various trips abroad was not one-off, but like a snowball effect. My first tour, at such a young age, whether or not I realized it made me aware of my own existence amongst so much variety; of art, personalities, ethnicities, nations, customs, cultural settings and the nature that shaped them. The experience of travelling abroad frequently, of meeting, mixing with and watching arts from other countries, or from other areas of Indonesia at the Istana Negara and at the training centre before we left on the cultural missions, all, consciously or not, imprinted upon and influenced the arts we practiced.

Our preparation at the training centre before departure had many advantages, both for the Department of Education, Train- 
ing and Culture and for the artists themselves. For the former, as the body in charge of the cultural missions, the training offered the opportunity to ensure the quality of the performances matched expectations and that they were compact and well coordinated. Secondly, the training centre experience fostered a sense of family between the members of the mission, which ensured that performances were of optimal standard.

For the artists themselves, the training experience gave them the opportunity to examine their own shortcomings and appreciate the skills of others. Secondly, artists increased their own knowledge about ways to improve the quality of performance. Thirdly, they could better appreciate the arts of other places in Indonesia. This appreciation of different beauty and techniques occurred spontaneously, without any deliberate direction, particularly because we had to help others during their performances; and fourthly, the training provided a source of many ideas, and honed our creativity and artistic sensitivities.

Dancing on professional stages abroad was another new experience for us. The stages were expansive and clean, the equipment complete, and we could sense the audience's connection with the performers because they were able to watch attentively. I felt at home on such stages, and could give my performance full expression, unlike performance conditions in Indonesia which were rarely like this, except for the stage at the Istana Negara.

My respect for the performances I observed of other amazing dancers on the missions, as well as the extraordinary artists on professional stages performing before audiences that watched so attentively, gradually influenced my own ideals and my own performance on stage. All my movements became more 'sensed', and my facial expression was no longer bland, but followed the movements and dynamics of the dance. The facial expression of Sundanese dance, which is usually restrained and invisible, was no longer really valid for me. The moment I heard the dance accompaniment and song, my face would react together with the dance movement and character. This might also have been the influence of watching and learning Balinese dance.

When I performed the Kandagan dance, the dynamics of which was between refined, agile and strong, my expression would follow automatically. In the tari Merak (Peacock dance) that depicted a peacock's pride in the beauty of its tail, the expression of pride had to be evident in both the dancer's face and body. And with dance in refined style, the same was true. The sense of refinement seemed to flow outwards from the 'heart' to the muscles and nerves, moving the hands and the whole body in a fluid way. 
For group dancing, witnessing the tightness and strong unison of movement of folk dancing in Eastern Europe, China and Korea made us aware that in executing group dancing we had to appear as though a single person seen in many reflections. This was something that inspired me when I gave training in group dancing, from the shape and feel of the dance, to the movements of the hands, body, head and eyes.

Apart from the tight unison of both European folk dancing and Swan lake, I observed complex floor patterns in dance. Attention to clean transitions from one floor pattern to the next using clean movement and distance, assisted me when my teacher Tjetje Somantri suddenly asked me to help with preparations for the 'colossal' dance Sri Gati (depicting rice planting) by 24 dancers for the Asian Games in 1962 and the Srenggana dance (Red ant dance) by 30 dancers for Games of the New Emerging Forces (GANEFO) in 1963. The performance stage was unusual, namely the huge sports stadium at Senayan (Gedung Istora) in Jakarta, and the performance was for an invited audience that included President Soekarno and all the Games participants from various countries.

\section{INFLUENCE ON SUNDANESE DANCE}

As an example of the interrelationship between the development of dance in Indonesia (Sunda) and participation in cultural missions abroad, I will explain two personal experiences, because my own choreography was significantly influenced by my travels as a member of the Soekarno era cultural missions. The first example is my choreography of the tari Merak (Peacock dance), and the second is the influence of my nationalistic awareness in forming the Viatikara group, with its 'new Indonesian dances' ('tari Indonesia baru') in fresh, attractive style in the form of 'modern Indonesian national dance drama' ('sendratari nasional Indonesia modern', the word sendratari coming from seni-drama-tari) which was extremely popular at the time.

The first Sundanese dance I arranged was the tari Merak based on Tjetje's dance from 1955. I had been appointed dance trainer for the Sundanese group in the Indonesian contingent for the second year of the New York World's Fair (1965). As it turned out, Indonesia withdrew from the New York World's Fair in 1965 in protest at the participation of Malaysia (this was the height of Indonesia's Confrontation with Malaysia), and the artists did not tour to 
New York. The dance that was to be taken to New York was first performed in North Korea, as part of the (1965) presidential cultural mission to North Korea, PRC and Japan.

In 1964, the first year of the New York World's Fair (AprilOctober) in which Indonesia did participate, the Sundanese program had included the Kukupu dance. As a change from this for the second year, I remembered my teacher's Merak dance, which had not been very popular. I found peacocks beautiful and graceful. I had studied this dance with Tjetje Somantri, but did not like it because I thought it did not capture the spirit of the peacock, either in the movement or the costumes. I was determined to rediscover this dance, and I began to explore the movements on my own.

For instance, I took the step known as keupat used in the Sulintang dance and added bird-like movements for the hands, head and body, drawing on Balinese and Sundanese dance and ballet, and this became a new step known as keupat merak. I particularly liked a

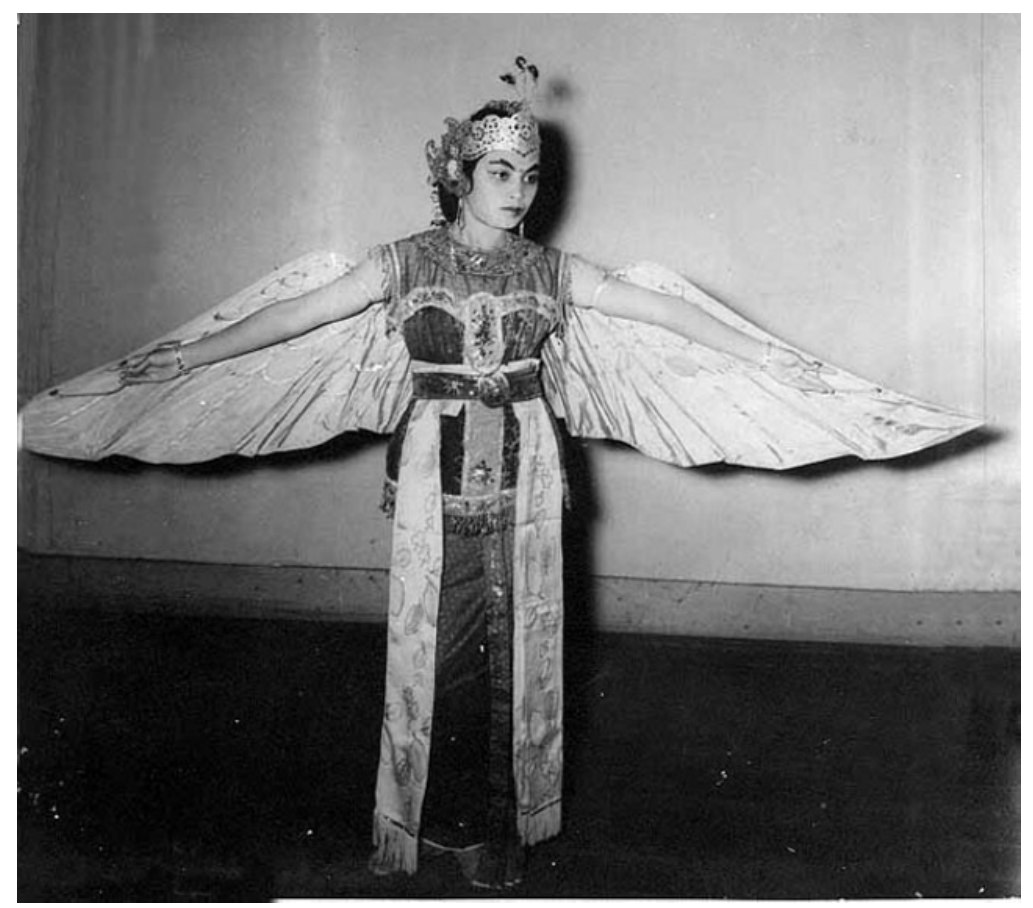

Tari Merak (Peacock dance), Tjetje Somantri's version.

(collection Irawati Durban Ardjo) 
movement of the body leaning deeply to the left and then twisting to the right as found in the Balinese Temulilingan dance created by I Mario. As the peacock's body is naturally tilted, not rigid, I took this technique and matched it with a hand movement, open with quivering fingers, and finally with feet movement influenced by ballet, with one foot on tiptoe and the other raised.

Ballet was one style of dance that fascinated me. As mentioned above, I had visited the Bolshoi ballet school in 1957. The grace, suppleness, power and dynamics of ballet always captivated me, and I could relate personally to its difficult acrobatic technique that seemed essential to ballet. Whenever I watched either live performances or films of ballet, I imitated the movement until I felt I 'got it'. Thus, when I came to choreograph the Merak and other dances, I incorporated elements of ballet.

Tjetje had given the example of the foot movement, trisik, in the Sulintang dance, with a full turn taken over a few steps. I added the pirouette, or full turn in one step, at the beginning of the trisik movement in the Merak dance. To complete this move, I adopted the essence of a movement I had seen in the African Kaswari bird dance at the South African pavilion at the New York World's Fair in 1964. The bird would move the base of its wings near the shoulders when it opened and closed its wings. I used this movement, which was also widely adopted in American modern dance, for the shoulders as the dancers spread the peacock tail at the end of the trisik step. There were also other elements of ballet that I inserted to strengthen the graceful and proud character of the peacock.

The process of creating this dance was swift. Together with the gamelan musicians, it took only three afternoons, while joking with my friends who were my models. To accompany the kokoer (scratching) movement, I asked Kayat to use the other end of the bonang sticks, so that the wood against bronze, played at fast tempo, would give a clear sound like Balinese gamelan to accompany the fast steps. Tjetje had already pioneered the adoption of dance movement from other areas, stressing that these movements had to meld into Sundanese dance, and should not look like collage. His Sulintang dance contained elements of Balinese, Javanese, Burmese and Indian dance, but the audience saw it as Sundanese.

When it came to designing the costumes, I wanted the beauty and elegance of the peacock seen clearly in the costume. The dance properties had to reinforce the dance movements. This was the first time my sister-in-law, ceu Itim, later known as Ibu Kusumah, made peacock costumes following my designs. The artist Barli designed the motifs for the tail and the body feathers. 
In Tjetje's Merak dance, the dancers held the flying peacock wings as they executed the trisik step. In my version, I wanted to highlight the tail display as the source of the bird's charm. But the tail points up, and if the costume were made like that it would interfere with the movement. I searched for another idea. In the People's Republic of China, the peacock dance I had seen was performed by seven dancers wearing a wide, flowing light green dresses with feather-motif at the base. I found this costume not 'peacock' enough. My idea was that the feather motif also had to be visible on the torso. The peacock tail motif should be seen on the cloth, and the semi-circular tail display shown by the dancers holding the cloth draping from their shoulders, using both hands as they executed the trisik. The movement had to be full of pride. The peacock's was represented with a tall headpiece topped with three points.

In this way, and with such ease, the Merak dance was conceived and performed. The first costumes were designed for the Viatikara group that was supposed to perform at the New York World's Fair in 1965. I later developed the dance further, adding three more movements, at the invitation of Aang Kuneafi, the wife of the Governor of West Java, for a performance by 12 dancers at the 25th anniversary of the Asia-Africa Conference, held in Bandung in 1980. Since 1965, this dance has remained popular with the public and is still frequently performed for formal and informal events both in Indonesia and abroad. In 2006, the office of Tourism and Culture (Dinas Pariwisata dan Kebudayaan) made the dance an official icon of West Java.

THE SEARCH FOR DANCE FORMS FOR A NEW INDONESIA

When Indonesia was newly independent, those at the forefront of the arts, working either independently or collectively in cultural, political, religious or other groups, were searching for ways to be innovative in Indonesian dance, as the time demanded and according to their own particular missions and visions. This was also true of Bandung. From the 1950s, the new republic was searching and striving for a form of unity in art that, it was hoped, would bind Indonesian-ness from the many scattered areas of the archipelago. The Youth Pledge (Sumpah Pemuda) back in 1928 had stated: One nation, one people, and the language of unity, Indonesian. In the 1950 s, people had begun to wonder, was there such a thing as 'Indonesian dance' that could be danced by all the peoples of the archipelago? 
As it happened, the new choreography by Sauti from Medan in 1956 based on Malay dance and called Serampang XII (the name was usually written with roman numerals) was accepted as a national Indonesian dance. I wanted to know why this could happen, and whether it was because the source of the Indonesian language was Malay. Actually, the dance had been the initiative of the Department of Education, Training and Culture in Jakarta, and taught by Sauti in Bandung, Jakarta and many other places. I myself had the opportunity to learn Malay dance taught by Sauti in 1958 at courses organized by the West Java P.P. \& K. office in Bandung. The dance caught on, and many young people opened Serampang XII courses, which culminated in Serampang XII competitions held at village, municipal and even national level.

The enthusiasm for innovating traditional dance by giving it new form and placing it in a new position seemed to affect many places; Sunda (Tjetje), Makassar (Nurhani), Malay (Sauti) and Bali (I Mario). The dance group Viatikara in Bandung, however, seeing the way that Serampang XII had been adopted in so many places in Indonesia, pursued the drive to find Indonesian dance forms in a different way, namely through its attempts to fuse various elements of regional dance into a new, fresh 'nationalistic' form.

At the time, even though I was still Tjetje's student and dancer, I had widened my arts activities and moved from strictly Sundanese dance to new creations (kreasi baru) with the Viatikara group which since 1959 had been led by Drs. Barli Sasmitawinata and the choreographer Paul Kusardy Polim. Barli was a painter who had been part of the Sekar Pakuan group from 1935, together with others of his colleagues from the Kelompok Lima Bandung (Bandung Group of Five) including Affandi, Wahdi, Hendra Gunawan and Sudarso. They had remained with Oemay at the Keimin Bunka Shidoso during the Japanese occupation through to the early BKI days. Paul Kusardy was a student in the economics department of Parahyangan University in Bandung who studied ballet, and Sumatran and Javanese dance.

I enjoyed working with the Viatikara group, because at the time all artists were madly following the trend to find a new colour for Indonesian art. Paul Kusardy's new creations had elements of traditional dance and ballet, which provided an outlet for the dance movement my own body had absorbed (Sundanese, Malay, ballet), and I was also able to contribute to ideas about new dance movement. As a young person, I could move freely mixing these elements without giving any one too much emphasis. The accompanying music, too, was created with Western instruments (the Togaso Band) together with Sundanese flute and drum, and singing. 
As was fitting for its Sanskrit-sounding name that meant something like 'blend', Viatikara's dances were varied in form but all had a strong traditional colour. Various elements of regional dance were adopted and fashioned by inserting other elements which made the work seem new and fresh, both conceptually and in performance. With the uncomplicated thinking of the time and within the limits of our knowledge about choreography and music, we took regional dance movements, ballet, regional songs and Indonesian songs, and mixed them in the search for a colour of new Indonesian dance that was more dynamic and 'modern'; (in those days, something that was new and had Western influence was called 'modern'). Prior to 1964, Viatikara's name was initially 'Sendratari Nasional/Indonesia Modern' (modern national/Indonesian dance drama).

Viatikara's dances were born full of enthusiasm and high ideals: dances like the tari Petik (Tea-picking dance, Sunda); Kupu dan bunga (Butterflies and flowers, Sunda-Indonesia), Kunang-kunang (Fireflies, Sunda-Indonesia), Putri gunung (Mountain princess, Java), Rebana (Sunda, Sumatra, ballet), Angin timur (Wind from the East, Sunda-Sumatra-Bali), Kuda lumping (Hobby-horse, SundaBetawi), Potong padi (Rice-harvesting, Sunda-Indonesia), Nelayan (Fishermen, Sunda-Indonesia) and dance dramas (sendratari) such as Hari yang cerah (Bright day, Minang-Batak-Ambon) and Lutung Kasarung. The audiences who watched them were just as enthusiastic as the performers. The uniqueness of Viatikara's performances was that they were always compact and were a whole, from the dancers, singers, musicians, the simple artistic decor, high quality lighting and sound, and the energetic performers and crew. Many young dancers in other regions later copied this style of dance and presentation.

In the early 1960s, the Bayanihan group from the Philippines visited Bandung. The dances they performed were of great interest. The ethnic flavour was still strong, but with a romantic Spanish influence. The impression they gave was of a mix between tradition and the West, rather like what Viatikara was doing. This helped strengthen our resolve that Viatikara was on the 'right track' in the search for 'new Indonesian dance'. Bayanihan's elegant, light style was similar, although the costumes were different. Bayanihan appeared in the elaborate richness of Philippine and Spanish tradition, whereas Viatikara, in keeping with the context of the time which tended towards modern-traditional, used simple properties with no ornament at all. Barli, the leader of our group and also costume designer, created simple, modern costumes from cotton in plain contrasting colours, but fashioned using traditional elements. 
In fact, these costumes were in keeping with the themes of 'the people' and 'work' that were then in vogue and influenced by the politics promulgated by the Indonesian Communist Party (Partai Komunis Indonesia, PKI), which was influential through its affiliated cultural organization, LEKRA. ${ }^{8}$

In relation to this popular spirit of the time, Viatikara, even though it had no link to LEKRA ideologies, was also influenced by the visiting arts groups from PRC and Vietnam that performed in Bandung. Their Farmer's dance and Tea-picking dance inspired Kusardy Polim to create similar dances. The program for Indonesia's 1965 Presidential Cultural Mission to PRC and North Korea was dominated by dance with 'work' and 'heroic' themes commissioned by the Minister of Education, Training and Culture, Professor Dr. Priyono as the group leader. Responding to the demand for such thematic dances, Yogyakarta prepared the Batik dance, Bali had the Weaving dance (tari Tenun) and Fishermen's dance (tari Nelayan). I prepared the Sri Gati dance from Sunda for five dancers similar to the one that had been performed at the Asian Games. My answer to the demand for a heroic theme was to change the solo dance of Ratu Graeni practising wielding her kris to the Suraningpati dance by five heroic female warriors, to heighten the rhythm of the gamelan accompaniment, and expand the play with the kris.

I began to feel the need for a method of physical training for Sundanese dance when I saw that not all students could easily follow the dance movements. I then recalled the basic training that I had seen in Moscow and in Thailand.

Both classical ballet and Thai classical dance require rehearsal exercises that must be introduced incrementally to achieve flexibility and train difficult dance technique. In ballet, execution of an arabesque or the splits requires long, difficult practice. So too with the classical Thai dance I saw at the Royal Dance Academy in Bangkok. Students whose fingers were not flexible enough had to practice bending their fingers against the wall, pushing the whole

8 Basically, in LEKRA's view, dance that grew alongside human life, had to become an artistic product that had purpose for human life. The power of dance to grow and develop also had to be in harmony with the development of society, capable of arousing revolutionary spirit, and national in form. In the renovation of regional dance to become national dance, progressiverevolutionary artists had to consider the ideological side, not merely the artistic side (Rhoma D.A.Yuliantri and Muhidin M. Dahlan 2008:394, 400). 
weight of their bodies until the fingers could reach back and touch the hand. Those who could not yet stand with their bent knees and feet open making a perfectly straight line, had to stand at the wall and every day a friend gradually pushed their knees until they were flush against the wall.

In the dance of Viatikara or in Sundanese dance, there is no such difficult technique. Nevertheless, adapting to the needs of the time and in order for students to learn to dance more quickly, I thought that physical exercises should be considered and tried by isolating the movement technique most frequently used by different parts of the body. These exercises were to loosen up the muscles and joints and to make the body absorb the movements and store them in physical memory.

\section{ONGOING INFLUENCE}

The influence of the state performances and the cultural missions I outlined above, was not something subsequently swallowed by time. The memory of events that made such an impression continued to influence the steps I took and the challenges I faced thereafter. The example of President Soekarno's intense interest in Indonesian arts, his appreciation and pride in them, in both national and international forums, fostered a similar feeling in arts lovers and artists, including myself. His enthusiasm for the existence and development of traditional regional art infected my concern that these arts might be crushed by undirected progress. In an attempt to give some direction, apart from creating new choreography, I also concentrated on the teaching of dance to younger generations at primary and junior high schools as well as at my own Pusbitari dance studio.

The dance of the Soekarno era has long past, and many people have forgotten it, particularly because of the political situation and the cultural policy in Indonesia which changed radically after the 30 September-1 October 1965 coup and the beginning of General Soeharto's 'New Order' in 1966. But actually, the artistic seeds which, in the 'Old Order', were planted in the hearts of artists from all over Indonesia who were invited to perform before President Soekarno, in their own regions or at the state palace, in Jakarta or on cultural missions abroad, continues to bear fruit as experience that strongly influenced both them personally and the development of the arts in Indonesia.

Translated from Indonesian by Jennifer Lindsay 
Irawati Durban Ardjo

REFERENCES

Irawati Durban Ardjo

2007 Tari Sunda 1880-1990; Melacak jejak Tb. Oemay Martakusuma dan Rd. Tjetje Somantri. Bandung: Pusbitari Press.

2008 Tari Sunda 1940-1965; Rd. Tjetje Somantri dan kiprah BKI. Bandung: Pusbitari Press.

Rhoma Dwi Aria Yuliantri dan Muhidin M. Dahlan (eds)

2008 Lekra tak membakar buku. Yogyakarta: Merakesumba.

Tb. Oemay Martakusuma

1977 'Riwayat berdirinya BKI (Badan Kesenian Indonesia)'. [Manuscript.]

Tom (Tb. Oemay Martakusuma)

1952 'Selajang pandang tentang kesenian daerah Djawa Barat', Budaya 21:38. 